\title{
Sequence Stratigraphy of the Yeongweol Group (Cambrian-Ordovician), Taebaeksan Basin, Korea: Paleogeographic Implications
}

\author{
Y.K. Kwon* \\ Korea Institute of Geoscience and Mineral Resources, Daejeon 305-350, Republic of Korea
}

\section{전기고생대 태백산분지 영월층군의 순차층서 연구를 통한 고지리적 추론}

\author{
권 이 균* \\ 한국지질자원연구원 석유해저연구본부, 대전광역시 유성구 과학로 124
}

\begin{abstract}
전기 고생대 태백산분지 영월층군은 탄산염-규산쇄설성 퇴적암 복합체로서 하부로부터 삼방산층, 마차리층, 와곡층, 문 곡층, 영흥층으로 이루어져있다. 영월층군에 대한 순차층서학적 분석에 따르면 중기 캠브리아기에 일어난 범람에 의해 최하부의 규산쇄설성 사질 퇴적암이 우세한 삼방산층이 퇴적되었다. 이어지는 후중기 캠브리아기 전후기 캠브리아기 에 지속적으로 발생한 빠른 해수면 상승으로 마차리층 하부에는 셰일, 입자암, 각력암층을 협재한 사면 혹은 심부 램프 시퀀스가 형성되었다. 후기 캠브리아기 동안 지속된 해수면 상승은 실질적인 퇴적가능공간을 창출하였고, 조하대 환경에 탄산염 퇴적물 공장이 만들어졌으며, 탄산염 대지에는 마차리층을 구성하는 탄산염암이 우세한 조하대 시퀀스가 형성되 었다. 마차리층 상부의 와곡층은 후후기 캠브리아기의 완만한 해수면 상승국면에서 만들어진 탄산염 램프 시퀀스로 해 석되며, 퇴적 당시에는 리본 탄산염암과 탄산염 역암을 포함하는 이회암으로 구성되었던 것으로 보인다. 와곡층은 퇴적 직후에 일차적으로 캠브리아기와 오르도비스기 사이의 해수면 하강국면에서 불안전 백운암화 과정을 거치고, 후에 심부 매몰 속성환경에서 광범위한 백운암화 작용을 받은 것으로 해석된다. 전기 오르도비스기에도 세계적인 해수면 상승과 해 침은 지속되었으며, 영월층군의 조하대 램프 퇴적환경은 그대로 유지되어 탄산염 역암층을 협재하는 석회이암과 이회암 이 교호하는 전형적인 램프 시퀀스인 문곡층이 형성되었다. 문곡층은 중기 오르도비스기에 퇴적된 것으로 알려진 영흥 층에 덮여 있다. 영흥층은 주로 윤회층리를 보이는 조석대지 탄산염암으로 이루어져 있으며, 문곡층의 최상부에서 조하 대 퇴적환경이 영흥층의 조석대지 퇴적환경으로 변화한다. 세계적 1차 규모 순차 경계면인 소크(Sauk)와 티피카누 (Tippecanoe) 시퀀스의 경계는 영흥층 중부에서 관찰되는 최소퇴적가능공간 부근에서 인지된다. 중기 오르도비스기 초기 의 세계적 해수면 하강과 이어지는 해수면의 급격한 상승은 영흥층의 전반적인 상향 천해화 윤회층의 전진퇴적체를 형 성하였다. 영월층군이 퇴적된 영월 탄산염 대지의 상대적 해수면 변동곡선을 복원해 보면 같은 태백산 분지의 태백층군 이 퇴적된 태백 탄산염 대지의 해수면 변동 곡선과 유사함을 확인할 수 있다. 이것은 두 개의 탄산염 대지가 유사한 조 구조적 운동 역사를 갖는다는 것을 의미하며, 이러한 유사성은 영월층군이 형성된 영월 탄산염 대지가 비록 태백층군이 퇴적된 태백 탄산염 대지와 상이한 퇴적시스템을 갖기는 하지만 상대적으로 가까운 지역에 속해 있었음을 암시한다. 퇴 적층서 분석결과에 따르면 영월 탄산염 대지는 태백 탄산염 대지에 비해 상대적으로 열린 천해 환경이었을 것으로 추측 된다. 고생대 후기와 중생대 전기에 걸쳐 발생한 북중국지괴와 남중국지괴의 충돌 시기에 영월 탄산염 대지와 태백 탄 산염 대지가 복잡한 이동과정을 거쳐 현재의 태백산 분지에 모이게 된 것으로 해석된다.
\end{abstract}

주요어 : 고지리, 영월층군, 태백층군, 태백산분지, 순차층서

The Yeongweol Group is a Lower Paleozoic mixed carbonate-siliciclastic sequence in the Taebaeksan Basin of Korea, and consists of five lithologic formations: Sambangsan, Machari, Wagok, Mungok, and Yeongheung in ascending order. Sequence stratigraphic interpretation of the group indicates that initial flooding in the Yeongweol area of the Taebaeksan Basin resulted in basal siliciclastic-dominated sequences of the Sambangsan Formation during the Middle Cambrian. The accelerated sea-level rise in the late Middle to early Late Cambrian generated a mixed carbonate-siliciclastic slope or deep ramp sequence of shale, grainstone and breccia intercalations, representing the lower part of the Machari Formation. The

*Corresponding author: kyk70@kigam.re.kr 
continued rise of sea level in the Late Cambrian made substantial accommodation space and activated subtidal carbonate factory, forming carbonate-dominated subtidal platform sequence in the middle and upper parts of the Machari Formation. The overlying Wagok Formation might originally be a ramp carbonate sequence of subtidal ribbon carbonates and marls with conglomerates, deposited during the normal rise of relative sea level in the late Late Cambrian. The formation was affected by unstable dolomitization shortly after the deposition during the relative sea-level fall in the latest Cambrian or earliest Ordovician. Subsequently, it was extensively dolomitized under the deep burial diagenetic condition. During the Early Ordovician (Tremadocian), global transgression (viz. Sauk) was continued, and subtidal ramp deposition was sustained in the Yeongweol platform, forming the Mungok Formation. The formation is overlain by the peritidal carbonates of the Yeongheung Formation, and is stacked by cyclic sedimentation during the Early to Middle Ordovician (Arenigian to Caradocian). The lithologic change from subtidal ramp to peritidal facies is preserved at the uppermost part of the Mungok Formation. The transition between Sauk and Tippecanoe sequences is recognized within the middle part of the Yeongheung Formation as a minimum accommodation zone. The global eustatic fall in the earliest Middle Ordovician and the ensuing rise of relative sea level during the Darrwillian to Caradocian produced broadly-prograding peritidal carbonates of shallowing-upward cyclic successions within the Yeongheung Formation. The reconstructed relative sea-level curve of the Yeongweol platform is very similar to that of the Taebaek platform. This reveals that the Yeongweol platform experienced same tectonic movements with the Taebaek platform, and consequently that both platform sequences might be located in a body or somewhere separately in the margin of the North China platform. The significant differences in lithologic and stratigraphic successions imply that the Yeongweol platform was much far from the Taebaek platform and not associated with the Taebaek platform as a single depositional system. The Yeongweol platform was probably located in relatively open shallow marine environments, whereas the Taebaek platform was a part of the restricted embayments. During the late Paleozoic to early Mesozoic amalgamations of the Korean massifs, the Yeongweol platform was probably pushed against the Taebaek platform by the complex movement, forming fragmented platform sequences of the Taebaeksan Basin.

Key words : paleogeography, Yeongweol group, Taebaek group, Taebaeksan Basin, sequence stratigraphy

\section{Introduction}

The paleogeographic reconstruction of tectonic segments in the Korean Peninsula have been a significant issue during the past two decades (Ree et al., 1996; Chwae and Choi, 1999; Chough et al., 2000; Kim et al., 2001; Metcalfe, 2006; Oh, 2006; Zhai et al., 2007). A considerable amount of petrographicl, geochemical and geochronologic data have been accumulated, provided the basis for various models on paleogeography and tectonic history (e.g., Chwae and Choi, 1999; Lee and Kim, 2001; Zhai et al., 2003; Kim, 2005; Choi and Kim, 2006; Metcalfe, 2006; Oh, 2006; Oh et al., 2006; Zhai et al., 2007; Kwon et al., 2009). Recent stratigraphic and paleontologic studies, particularly from the Paleozoic Taebaeksan Basin, also contributed to unveiling paleogeography and paleo-depositional environments of pre-collision sedimantary basins (Chough et al., 2000; Choi and Chough, 2005; Choi and Kim, 2006; Kwon et al., 2006, Zhang et al., 2008; Woo et al, 2008).

The Yeongweol and Taebaek groups are principal lithologic units in the Lower Paleozoic Taebaeksan Basin (Fig. 1). They are typical Cambrian-Ordovician platform sequences composed of mixed carbonates and siliciclastics (Kobayashi, 1966; Cheong, 1969; Choi, 1998; Chough et al., 2000; Choi et al., 2004; Choi and Chough, 2005). The Taebaek Group is considered to represent a part of the North China platform (Chough et al., 2000; Kwon et al., 2003; Choi and Chough, 2005; Kwon et al., 2006), and are lithologically similar to the Lower Paleozoic sedimentary rocks in the North China platform (Meyerhoff et al., 1991; Meng et al., 1997; Choi, 1998; Choi et al., 2004). Recent sequence stratigraphic analyses also indicate that the Taebaek Group is well correlated with the mixed carbonate-siliciclastic successions of North China platform (Ryu et al., 2005; Kwon et al., 2006).

The Yeongweol Group is located in the western part of the Taebaeksan Basin, immediately west of the Taebaek Group (Fig. 2; Chough et al., 2000). In spite of the geographic proximity, it is lithologically distinct from the Taebaek Group, leading to considerable debate on the paleogeographic position of the Yeongweol platform during the Lower Paleozoic (e.g., Cluzel et al., 1991; Yin and Nie, 1993; Chough et al., 2000; Choi et al, 2001; Ryu et al., 2005; Choi and Kim, 2006). Cluzel et al. 


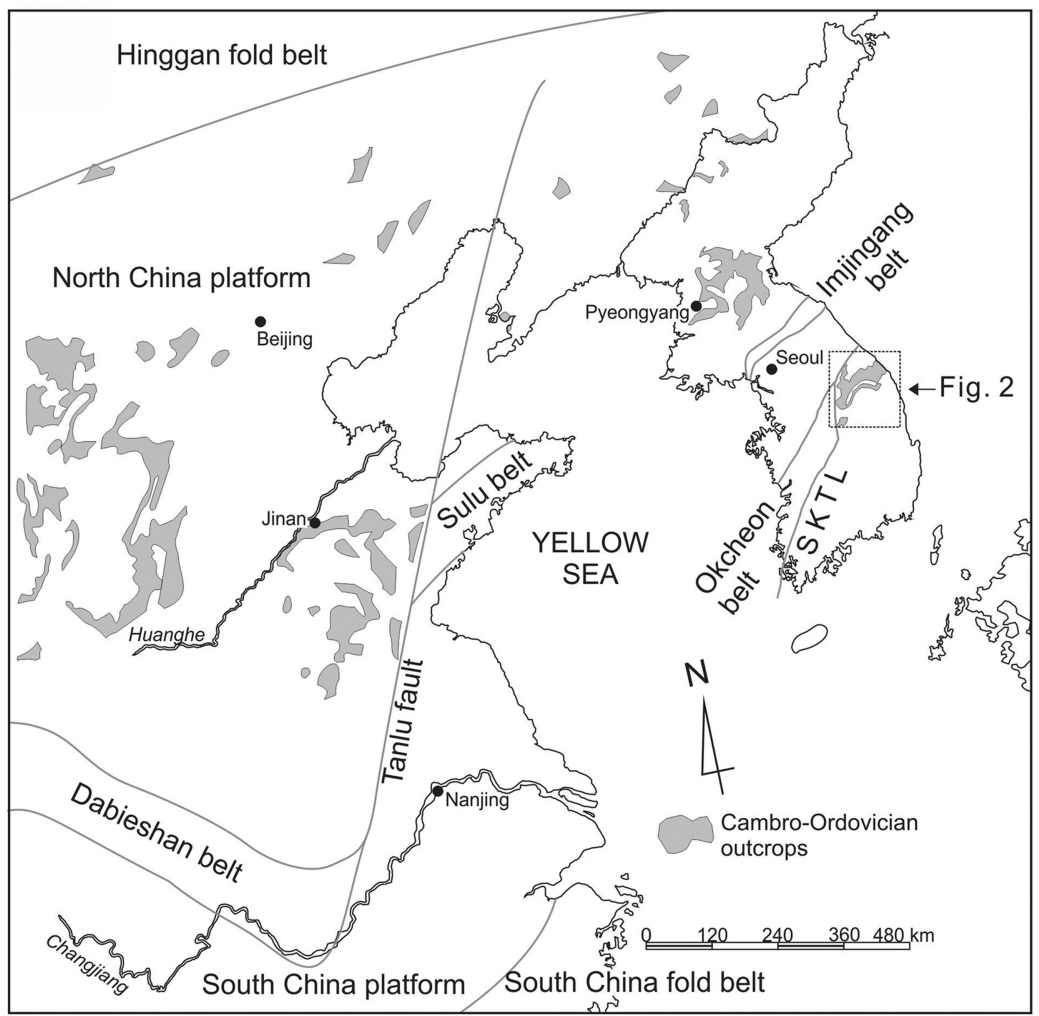

Fig. 1. Spatial distribution of the Cambrian-Ordovician sedimentary rocks in the Northeast Asia (after Y.K. Kwon et al., 2006).
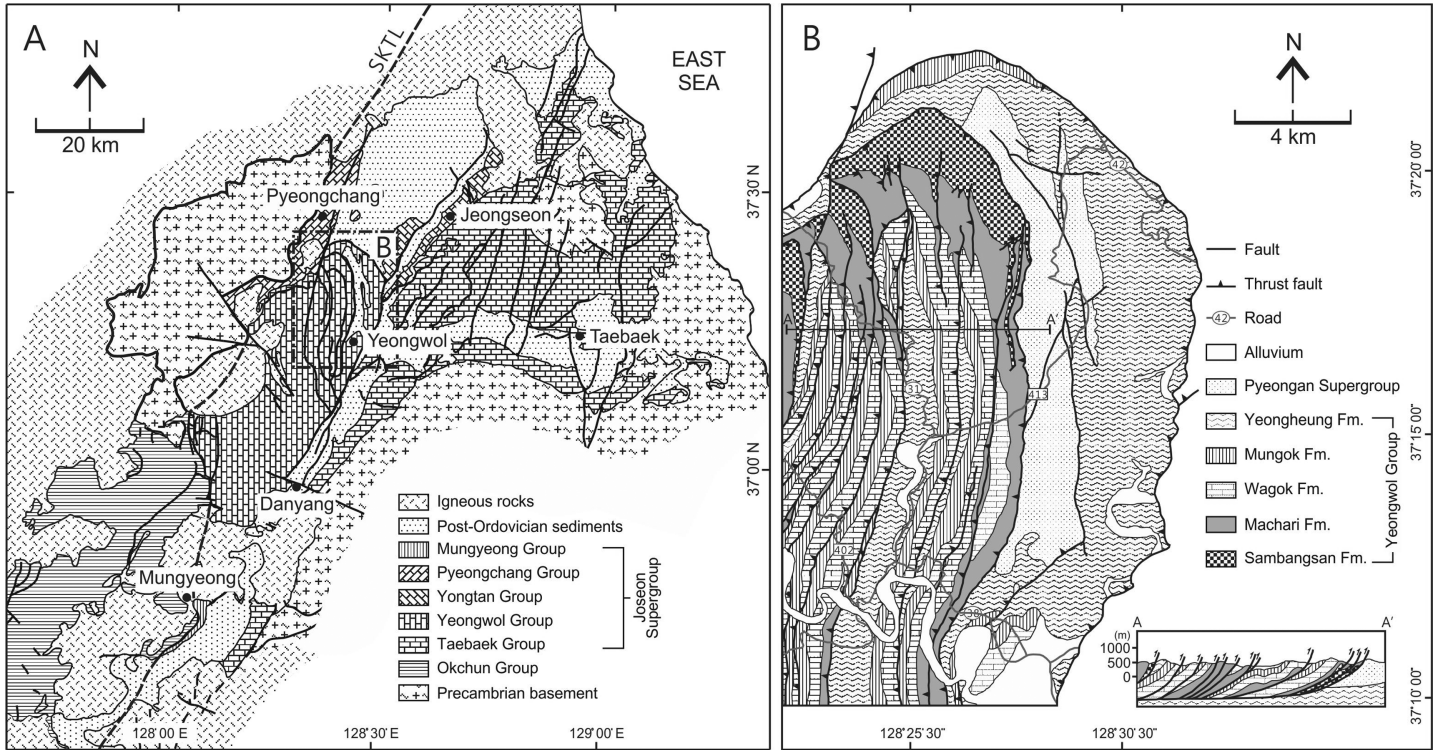

Fig. 2. Geologic map of the Taebaeksan Basin. (A) five lithologic groups of the Taebaeksan Basin, (B) geologic map of the Yeongweol group composed of the five lithologic formations (after Y.K. Kwon et al., 2006 and D.K. Choi, 1998). 
(1991) and Yin and Nie (1993) correlated the Yeongweol Group with the South China block. They also suggested that the Yeongweol and Taebaek groups were juxtaposed by a right-lateral transcurrent movement during the Permian-Triassic collision at the same time with the collision of the North China and South China blocks. On the other hand, Choi et al. (2001) and Choi and Kim (2006) suggested, on the basis of trilobite occurrence data, that the Yeongweol platform was involved in the North China platform.

This study aims to establish sequence stratigraphy of the Yeongweol Group and to examine the stratigraphic similarity between the Yeongweol and Taebaek groups. The sequence stratigraphic interpretation explains depositional scenario and vertical stacking patterns of the $2^{\text {nd }}$-order sequences and sedimentary response of mixed carbonatesiliciclastic systems to the sea-level fluctuations during the Early Paleozoic. The suggested depositional history of the group will help understanding of sedimentary systems of the Yeongweol Group and provide a significant foundation for the paleogeographic reconstruction of the Joseon Supergroup.

\section{Geologic Setting}

The Taebaeksan Basin is located in the mideastern part of the Korean Peninsula (Fig. 1). The basin consists of the Joseon Supergroup (CambrianOrdovician) and the unconformably overlying Pyeongan Supergroup (Carboniferous-Permian) (Fig. 2). The Joseon Supergroup comprises the mixed carbonate-siliciclastic sequences of sandstones, shales, and carbonates (Kobayashi, 1966; Woo and Park, 1989; Choi et al., 2004; Choi and Chough, 2005). This supergroup can be divided into five lithologically-different regional stratigraphic units: the Taebaek, Yeongweol, Yongtan, Mungyeong, and Pyeongchang groups (Fig. 2; Choi, 1998). Among these, the Yeongweol Group occupies the western part of the Taebaeksan Basin, bounded to the east with the Taebaek Group along the Gakdong thrust (Fig. 2). It consists of five lithologic members: Sambangsan, Machari, Wagok, Mungok, and Yeongheung formations in ascending order (Table 1; Kobayash, 1966; Choi, 1998; Choi and Chough, 2005). The basal Sambangsan Formation is a siliciclastic sequence composed of shale, siltstone and (locally gravelly) sandstone deposited mainly during the Middle Cambrian. The overlying Machari Formation is a mixed carbonate-siliciclastic sequence with limestone breccias and dolostone beds formed in the early Late Cambrian. The late Late Cambrian Wagok Formation is a white-gray dolostone sequence. During the Early Ordovician, the Mungok Formation was formed in the ramp-type subtidal carbonate platform, and is overlain by the Yeongheung Formation which mainly consists of peritidal carbonates.

\section{Lithostratigraphy}

For sequence stratigraphic interpretation, this study describes and identifies a total of 23 sedimentary facies, which are grouped into 11 facies association (Table 2 and Fig. 3).

\subsection{Sambangsan Formation}

The Sambangsan Formation is the basal lithostratigraphic unit of the Yeongweol Group, composed of siltstone, shale and sandstone (Fig. 3 and 4A), ranging in thickness from about $400 \mathrm{~m}$ to over $700 \mathrm{~m}$ (Choi and Chough, 2005). Based on trilobite assemblages, the formation is considered to be the Middle Cambrian in age (Choi et al., 1999).

The Sambangsan Formation is divided into two facies associations; the lower outer shelf (OS) and the upper inner shelf (IS) (Table 2 and Fig. 3). The lower OS facies association is dominated by purple and green siltstone and shale with some intercalations of limestone beds (Choi, 1998). The dominance of fine-grained sediments suggests that this facies association was deposited in an outer shelf environment.

The upper IS facies association consists predominantly of greenish gray, light brown, massive to thick-bedded, fine-grained micaceous sandstone, interbedded with siltstone, shale and limestone (Choi, 1998). Frequent intercalations of fine-grained sandstone beds of storm origin in the facies association represent an upward-shallowing transition from the underlying OS facies association.

\subsection{Machari Formation}

The Machari Formation overlies conformably the Sambangsan Formation and comprises shale, limestone breccia, argillaceous to dolomitic limestone and limestone pebble conglomerate. The thickness 
Table 1. Lithostratigraphic summary of the Yeongweol Group

\begin{tabular}{|c|c|c|c|c|c|}
\hline $\begin{array}{l}\text { Age } \\
(\mathrm{Ma})\end{array}$ & & & $\begin{array}{c}\text { Formation } \\
\text { (Thickness: meter) }\end{array}$ & Lithology & Biozone \\
\hline \multirow{17}{*}{$\begin{array}{l}\frac{\tilde{a}}{0} \\
\frac{0}{3} \\
0 \\
0 \\
0 \\
0\end{array}$} & 445 & Ashgillian & & & \\
\hline & \multirow{5}{*}{460} & \multirow{4}{*}{ Caradocian } & \multirow{10}{*}{$\begin{array}{l}\text { Yeongheung } \\
\quad(400)\end{array}$} & \multirow{10}{*}{$\begin{array}{l}\text { Massive packstone/grainstone } \\
\text { Bioturbated wackestone to grainstone } \\
\text { Oncoid/ooid grainstone } \\
\text { Limestone-shale couplet } \\
\text { Homogeneous mudstone } \\
\text { Laminated lime-mudstone } \\
\text { Massive or laminated grainstone } \\
\text { Limestone pebble conglomerate } \\
\text { Massive dolostone(breccia) } \\
\text { Stromatolitic limestone } \\
\text { Finely-laminated dolomitic limestone } \\
\text { Bioturbated wackestone to grainstone } \\
\text { Calcareous shale }\end{array}$} & \multirow{10}{*}{ Kayserapsis } \\
\hline & & & & & \\
\hline & & & & & \\
\hline & & & & & \\
\hline & & & & & \\
\hline & 468 & Darrwillian & & & \\
\hline & & & & & \\
\hline & \multirow{3}{*}{478} & \multirow{3}{*}{ Arenigian } & & & \\
\hline & & & & & \\
\hline & & & & & \\
\hline & & & & Limestone-shale couplet & \\
\hline & & & & Bioturbated or flaser-bedded limestone & \\
\hline & & & & Massive grainstone & Shumardia pellizzarii \\
\hline & & Tremadocian & $\begin{array}{l}\text { MungoK } \\
(140-210)\end{array}$ & Limestone pebble conglonerate & Kainella euryrachis \\
\hline & & & & Massive sandstone & \\
\hline & 488 & & & $\begin{array}{l}\text { Laminated or cross-stratified sandstone } \\
\text { Calcareous shale }\end{array}$ & \\
\hline \multirow{17}{*}{ 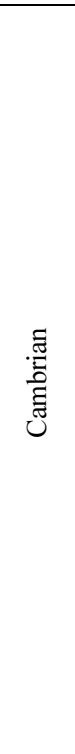 } & \multirow[b]{12}{*}{501} & \multirow{12}{*}{ Late } & & Massive grainstone & \\
\hline & & & Wagok & Calcareous shale & Fatocephalus hunjiangensis \\
\hline & & & & Limestone-shale couplet & \\
\hline & & & \multirow{9}{*}{$\begin{array}{l}\text { Machari } \\
(200)\end{array}$} & \multirow{9}{*}{$\begin{array}{l}\text { Bioturbated or flaser-bedded limestone } \\
\text { Massive grainstone } \\
\text { Limestone pebble conglomerate } \\
\text { Homogeneous or laminated mudstone } \\
\text { Massive or laminated sandstone }\end{array}$} & \multirow{9}{*}{$\begin{array}{l}\text { Pseudoyuepingia asaphoides } \\
\text { Agnostotes orientalis } \\
\text { Eochuangia hana } \\
\text { Eugonocare longifrons } \\
\text { Hancrania brevilimbata } \\
\text { Proceratopyge tenuis } \\
\text { Glyptagnostus reticulatus } \\
\text { Glyptagnostus stolidotus } \\
\text { Lejopvge armata } \\
\text { Tonkinella }\end{array}$} \\
\hline & & & & & \\
\hline & & & & & \\
\hline & & & & & \\
\hline & & & & & \\
\hline & & & & & \\
\hline & & & & & \\
\hline & & & & & \\
\hline & & & & & \\
\hline & \multirow[b]{5}{*}{513} & \multirow{4}{*}{ Middle } & & Limestone pebble conglomerate & \multirow{4}{*}{$\begin{array}{l}\text { Megagraulos semicircularis } \\
\text { Metagraulos sampoensis }\end{array}$} \\
\hline & & & Sanbangsan & Anastomosing wackestone to grainstone & \\
\hline & & & $(400-700)$ & Oncoid/ooid grainstone & \\
\hline & & & & Homogeneous or laminated mudstone & \\
\hline & & & & & \\
\hline
\end{tabular}

of the formation was estimated less than $200 \mathrm{~m}$ (Fig. 3; Lee, 1995). It is conformably overlain by massive dolostone of the Wagok Formation.

The Machari Formation is divided into three facies associations: the lower basin (BA), the middle basin to outer shelf (BA/OS) and the upper outer to inner shelf (OS/IS) facies associations (Table 2 and Fig. 3). The lower BA facies association consists of dark gray dolomitic limestone and shale with intercalations of limestone breccias and argillaceous limestone beds. Recently Hong et al. (2003) recognized the Lejopyge armata Zone from the dolomitic limestone beds. The limestone breccia in this facies association were interpreted as slope apron deposits (Chung and Land, 1997), although the evidence for mass flow movement is not convincing. In this study, this facies association is considered to have been deposited in a basin to 
Table 2. Brief summary of facies associations in the Yeongweol Group

\begin{tabular}{|c|c|c|c|}
\hline Formation & Facies Associations & Composite Facies & Sedimentary Environment \\
\hline \multirow{2}{*}{ Yeongheung } & $\mathrm{SS} / \mathrm{PT}$ & $\begin{array}{l}\text { Lime-mudstone } \\
\text { Oolitic grainstone } \\
\text { Peloidal grainstone to packstone } \\
\text { Stromatolitic limestone } \\
\text { Limestone pebble conglomerate }\end{array}$ & $\begin{array}{l}\text { Shallow Subtidal } \\
\text { or } \\
\text { Peritidal }\end{array}$ \\
\hline & PT & $\begin{array}{l}\text { Massive dolostone } \\
\text { Oolitic grainstone } \\
\text { Peloidal grainstone to packstone } \\
\text { Lime-mudstone } \\
\text { Cryptalgal laminate }\end{array}$ & Peritidal \\
\hline \multirow{3}{*}{ Mungok } & OS/IS & $\begin{array}{l}\text { Ribbon carbonate } \\
\text { Limestone pebble conglomerate } \\
\text { Lime-grainstone } \\
\text { Limestone-shale couplet }\end{array}$ & $\begin{array}{l}\text { Outer Shelf } \\
\text { or } \\
\text { Inner Shelf }\end{array}$ \\
\hline & $\mathrm{SS} / \mathrm{PT}$ & $\begin{array}{l}\text { Crudely-bedded dolostone } \\
\text { Limestone-shale couplet } \\
\text { Ribbon carbonate }\end{array}$ & $\begin{array}{l}\text { Shallow Subtidal } \\
\text { or } \\
\text { Peritidal }\end{array}$ \\
\hline & IS/SS & $\begin{array}{l}\text { Ribbon carbonate } \\
\text { Limestone pebble conglomerate } \\
\text { Limestone grainstone } \\
\text { Chert } \\
\text { Limestone-shale couplet }\end{array}$ & $\begin{array}{l}\text { Inner Shelf } \\
\text { or } \\
\text { Shallow Subtidal }\end{array}$ \\
\hline Wagok & $\mathrm{SS} / \mathrm{PT}$ & $\begin{array}{l}\text { Massive dolostone } \\
\text { Calcareous shale } \\
\text { Limestone-shale couplet }\end{array}$ & $\begin{array}{l}\text { Shallow Subtidal } \\
\text { or } \\
\text { Peritidal }\end{array}$ \\
\hline \multirow{3}{*}{ Machari } & OS/IS & $\begin{array}{l}\text { Thinly-bedded dolomitic limestone } \\
\text { Black shale } \\
\text { Limestone pebble conglomerate }\end{array}$ & $\begin{array}{l}\text { Outer Shelf } \\
\text { or } \\
\text { Inner Shelf }\end{array}$ \\
\hline & $\mathrm{BA} / \mathrm{OS}$ & $\begin{array}{l}\text { Laminated shale } \\
\text { Dolomitic limestone }\end{array}$ & $\begin{array}{l}\text { Basin } \\
\text { or } \\
\text { Outer Shelf }\end{array}$ \\
\hline & BA & $\begin{array}{l}\text { Dolomitic limestone } \\
\text { Shale } \\
\text { Limestone breccias } \\
\text { Argillaceous limestone }\end{array}$ & Basin \\
\hline \multirow[t]{2}{*}{ Sanbangsan } & IS & $\begin{array}{l}\text { Fine-grained sandstone } \\
\text { Siltstone } \\
\text { Shale } \\
\text { limestone }\end{array}$ & Inner Shelf \\
\hline & OS & $\begin{array}{l}\text { Siltstone } \\
\text { Shale } \\
\text { limestone }\end{array}$ & Outer Shelf \\
\hline
\end{tabular}

slope setting, based on the predominance of finegrained sediments, the occurrence of probable slope apron deposits, and no evidence for shallow water deposition.

The middle basin to outer shelf (BA/OS) facies is dominated by laminated dark gray to black shale and thin-bedded dolomitic limestone (Fig. 4B-C). This facies association has been known to be highly fossiliferous (Choi and Chough, 2005). The laminated black shale and abundance of cosmopolitan trilobite taxa in this facies association are suggestive of deposition in a dysaerobic deep-water environment (Chough et al., 2000). In this study, the depositional environment of this facies association is interpreted to have been shallower than that of the underlying BA facies association (basin to outer shelf setting), based on frequent intercalations of dolomitic limestone layers.

The upper outer shelf to inner shelf (OS/IS) facies association is characterized by alternations 


\section{Yeongweol Group}

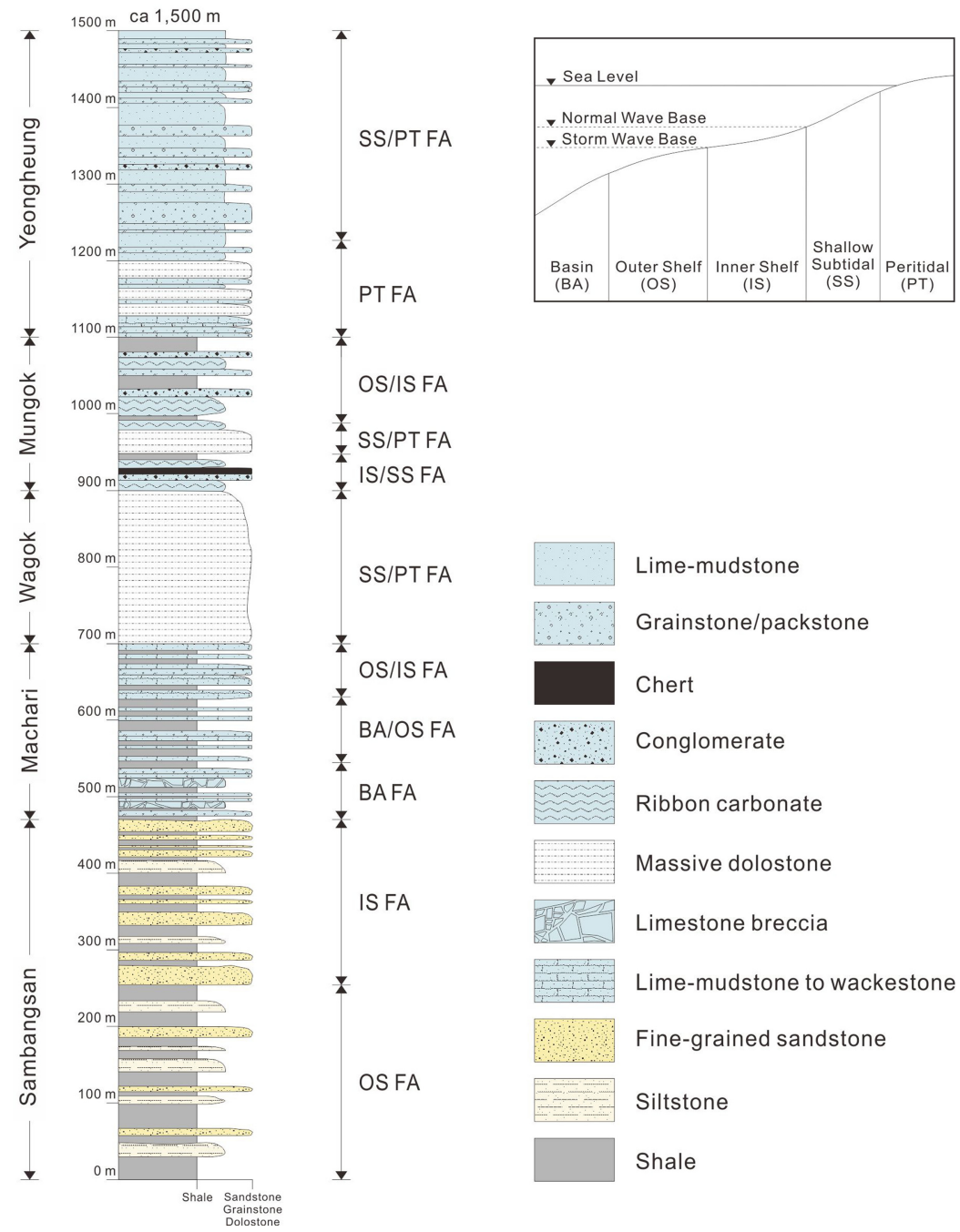

Fig. 3. Brief columnar description of the Yeongweol Group and vertical successions of the composite facies associations.

of thinly-bedded dolomitic limestone and black shale layers (Table 2, Fig. 3 and 4D). The alternations become progressively obscure toward the uppermost part of the formation which grades into massive dolostone of the Wagok Formation (Choi and Chough, 2005). Limestone pebble conglomerates are occasionally intercalated within this facies association. The depositional environment of this association is thought to have been similar to that of the underlying BA/OS facies association. However, some intercalated limestone pebble conglomerates of storm origin (Sepkoski, 1982; Kim and Lee, 1996), suggest that this association was deposited in an inner shelf setting near the storm wave base.

\subsection{Wagok Formation}

The Wagok Formation is characterized by a monotonous sequence of massive dolostone (Fig. 3 and 4E), and is poorly fossiliferous (Choi, 1998; Choi and Chough, 2005). Due to severe dolomization, it is difficult to recognize original grain components and sedimentary structures/textures 

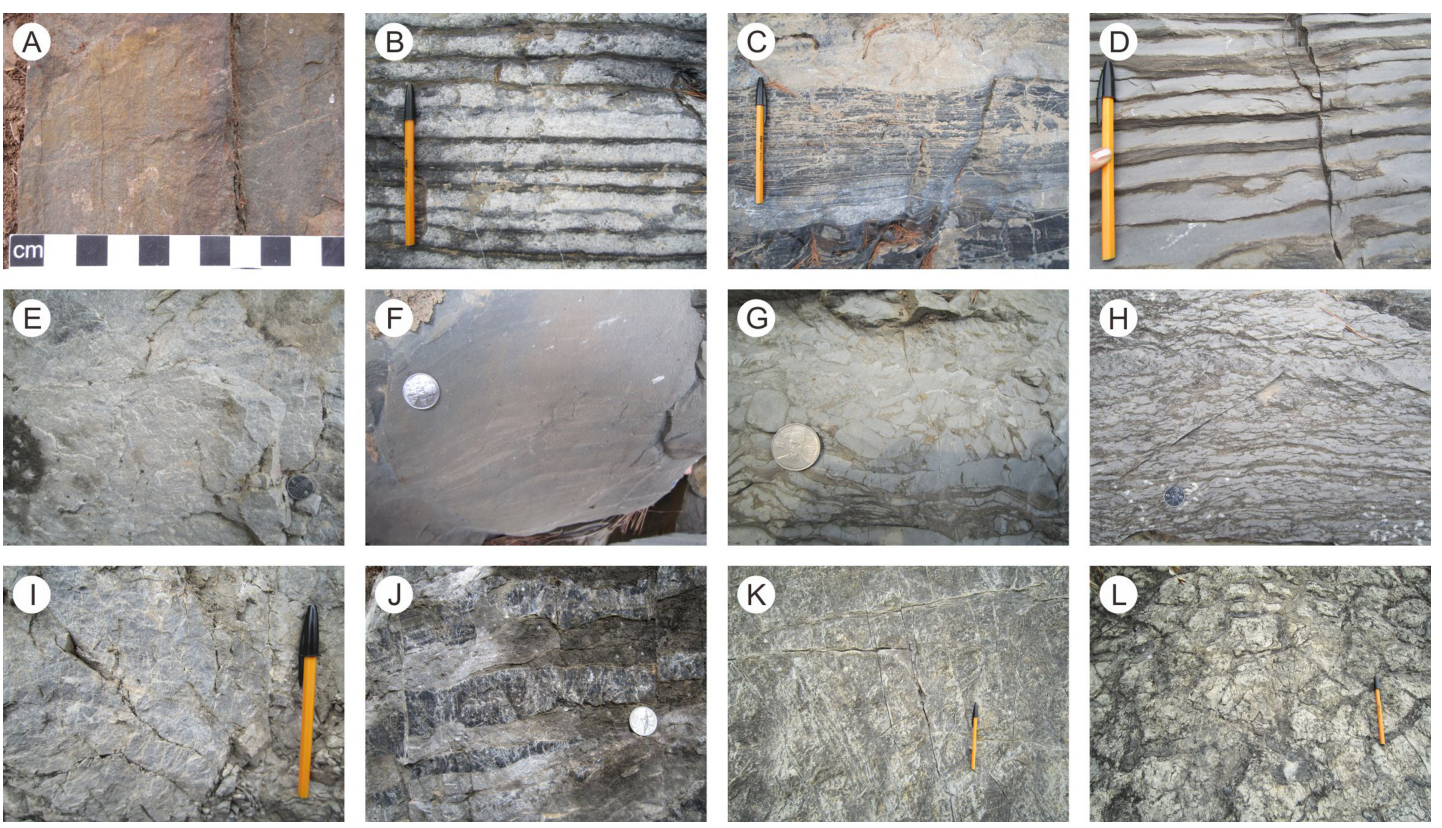

Fig. 4. Photographs of common sedimentary facies (scale bar in (A) is in cm; pen for scale in (B), (C), (D), (I), (K) and (L) is $15 \mathrm{~cm}$ long; coin for scale in $(\mathrm{E}),(\mathrm{F}),(\mathrm{G}),(\mathrm{H})$ and $(\mathrm{J})$ is $2.4 \mathrm{~cm}$ in diameter). A: Fine-grained sandstone, Sambangsan Formation; B: laminated shale with dolomitic limestone interbeds, Machari Formation; C: Thickly-bedded dolomitic limestone and black shale, Machari Formation; D: Thinly-bedded dolomitic limestone and black shale, Machari Formation; E: Massive dolostone, Wagok Formation; F: Marl, Mungok Formation; G: Limestone conglomerates, Mungok Formation; H: Ribbn Rock, Mungok Formation; I: Dolostone, Mungok Formation; J: Chert, Mungok Formation; K and L: Desiccation crack, Yeongheung Formation.

prior to the dolomitization. However, some relics of original components such as ooids, peloids, bioclasts and intraclasts can be occasionally observed where the dolomitization is not pervasive. The relics suggest that the dolostone may be originated from alternating facies of limestone and marl beds, limestone conglomerate, and bioclastic/peloidal grainstone. The formation has been known to range from 200 to $250 \mathrm{~m}$ in thickness (Park et al., 1994). Choi and Chough (2005) envisaged a shallow depositional environment above the wave base such as carbonate shoals where persistent grain mobility can be maintained by water turbulence or tidal activity. A shallow subtidal (SS) or pertidal (PT) facies association represents the Wagok Formation (Table 2).

\subsection{Mungok Formation}

The Mungok Formation consists of shale, marl, limestone conglomerate, and alternation of thinbedded limestone and shale (Fig. 4F-I). It has been divided into four lithologic members: basal, lower, middle and upper members in ascending order (Fig. 3; Kim and Choi, 2000). The basal member is composed mainly of ribbon carbonates and limestone conglomerates with intercalations of grainstone and chert layers. The lower member is characterized by a monotonous sequence of crudely-bedded dolostone. The middle member comprises ribbon carbonates and limestone conglomerates. The predominant facies of the upper member is marl to shale and ribbon carbonates with limestone conglomerate and grainstone interbeds. The total thickness has been known to range from $140 \mathrm{~m}$ to $210 \mathrm{~m}$ (Fig. 3; Choi and Chough, 2005). The formation has been interpreted to represent a shallow subtidal environment comprising lagoonal/ restricted marine, shoal, inner shelf, and outer shelf facies (Kim and Choi, 2002). The Mungok Formation consists of IS/SS, SS/PT and OS/IS facies associations (Table 2).

\subsection{Yeongheung Formation}

The Yeongheung Formation has been known to 
consist mainly of massive to thick-bedded dolostone in the lower part and of limestone-dominated sequence in the upper part (Fig. 3; Lee, 1987). Yoo et al. (1994) described the composite facies of this formation (Table 1), suggesting that the formation shows vertical stacking of shallowing-upward successions. However, the base and top of the formation are not well defined and the lithologic successions vary from section to section (Yoo et al., 1994; Choi and Chough, 2005). The formation was estimated to be about $400 \mathrm{~m}$ in thickness, interpreted as shallow subtidal and peritidal successions (Fig. 3; Yosimura, 1940; Choi and Woo, 1993; Yoo et al., 1994). The Yeongheung Formation is composed of PT and SS/PT facies associations (Table 2).

\section{Bio- and Chrono-stratigraphy}

A total of 17 biozones have been recognized within the Yeongweol Group, based on trilobite assemblages (Table 3; Choi and Chough, 2005).
Additionally, stromatolite, graptolite, and conodont biozones are also employed for the biostratigraphy and chronostratigraphic correlations.

The lowermost Sambangsan Formation includes Metagraulos sampoensis and Megagraulos semicircularis zones (Choi et al., 1999). The trilobite biozones indicate a deposition of the middle Middle Cambrian. The upper part of the Myobong Formation and lower part of Daegi Formation of the Taebaek Group are considered to have been formed during this period. The overlying Machari Formation consists of ten biozones. The lower three biozones (Tonkinella, Lejopyge armata, and Glyptagnotus stolidotus zones) correspond to the late Middle Cambrian. The upper seven biozones (Glyptagnostus reticulates, Proceratopyge tenuis, Hancrania brevilimbata, Eugonocare longifrons, Eochuangia hana, Agnostotes orientalis, and Pseudoyuepingia asaphoides zones) indicate an age of the Furongian (Late Cambrian). In the Wagok Formation, only one biozone, Fatocephalus hunjiangensis Zone, was recognized, suggesting an age

Table 3. Biostratigraphic summary of the Yeongweol and Taebaek groups (modofied after Duck K. Choi and Sung Kwun Chough, 2005)

\begin{tabular}{|c|c|c|c|c|c|}
\hline & \multirow{2}{*}{ Age } & \multicolumn{2}{|c|}{ Taebaek Group } & \multicolumn{2}{|c|}{ Yeongweol Group } \\
\hline & & Formation & Biozone & Formation & Biozone \\
\hline \multirow{6}{*}{$\begin{array}{l}\frac{0}{0} \\
\frac{0}{2} \\
\frac{0}{0} \\
0\end{array}$} & \multicolumn{5}{|l|}{ Ashgillain } \\
\hline & \multirow{2}{*}{ Caradocian } & Diwibong & & \multirow{3}{*}{ Yeongheung } & \multirow{3}{*}{ Kayserapsis } \\
\hline & & Jigunsan & Dolerobasilicus & & \\
\hline & Darriwilian & Makgol & & & \\
\hline & Arenigian & Dumugol & $\begin{array}{l}\text { Kayseraspis } \\
\text { Protopliomerops } \\
\text { Asaphells }\end{array}$ & \multirow[t]{2}{*}{ Mungok } & \multirow{2}{*}{$\begin{array}{l}\text { Shumardia pellizzarii } \\
\text { Kainella euryrachis } \\
\text { Yosimuraspis vulgaris }\end{array}$} \\
\hline & Tremadocian & Dongjeom & Pseudokainella & & \\
\hline \multirow{13}{*}{. } & \multirow{6}{*}{ Furongian } & \multirow{6}{*}{ Hwajeol } & Eoorthis & Wagok & Fatocephalus hunjiangensis \\
\hline & & & Dictyites & \multirow{8}{*}{ Machari } & Pseudoyuepingia asaphoides \\
\hline & & & Kaolishania & & $\begin{array}{l}\text { Agnostotes orientalis } \\
\text { Eochuangia hana }\end{array}$ \\
\hline & & & & & Eugonocare longifrons \\
\hline & & & Chunagia & & Hancrania brevilimbata \\
\hline & & & Prochuangia & & Glyptagnostus reticulatus \\
\hline & \multirow{6}{*}{ Middle } & \multirow{2}{*}{ Sesong } & Drepanura & & Glyptagnotus stolidotus \\
\hline & & & Stephanocare & & Lejopyge armate \\
\hline & & \multirow[b]{2}{*}{ Daegi } & Olenoides & & Tonkinella \\
\hline & & & $\begin{array}{l}\text { Solenoparia } \\
\text { Megagraulos }\end{array}$ & \multirow[t]{4}{*}{ Sambangsan } & \multirow{2}{*}{$\begin{array}{l}\text { Megagraulos semicircularis } \\
\text { Metagraulos sampoensis }\end{array}$} \\
\hline & & \multirow[b]{2}{*}{ Myobong } & Bailiella & & \\
\hline & & & $\begin{array}{l}\text { Mapania } \\
\text { Elrathia } \\
\text { Redlichia }\end{array}$ & & \\
\hline & Early & Jangsan/Myeor & & & \\
\hline
\end{tabular}


of the latest Cambrian.

The Mungok Formation contains three biozones (Yoshimuraspis vulgaris, Kainella euryrachis, and Shumaridia pellizzarii zones), corresponding to the Tremadocian of the Early Ordovician. In the lower Yeongheung Formation, only one biozone, Kayseraspis Zone, was recognized, indicating an age of the Arenigian (Choi and Chough, 2005). However, Cho and Kim (2007) based on graptolite occurrence, suggested that the lowermost part of the Yeongheung Formation corresponds to an age of the latest Tremadocian. The occurrence of a stromatoporoid, Labechia regularis in the middle part of the Yeongheung Formation is indicative of the Llanvirnian (Middle Ordovician). The conodont biozones of the formation also indicate the time span from Arenigian to Caradocian (Lee, 1987).

\section{Sequence Stratigraphy}

In the Taebaek platform, the Sauk transgression inundated topographic lows of the Precambrian basement of granitic gneiss and meta-sedimentary rocks during late Early and early Middle Cambrian (Kwon et al., 2006). During the early Sauk transgression, most of the Taebaek region was submerged, whereas the Yeongweol platform was most likely exposed until early Middle Cambrian (Fig. 5A).

In the middle Middle Cambrian, initial flooding in the Yeongweol platform formed siltstone and shale sequences in the lower part of the Sambangsan Formation (Fig. 3). A gradual decrease of sea-level rise resulted in progradation of nearshore sandprone facies, which generated sandstone-dominated sequence in the upper part of the Sambangsan Formation (Fig. 5B). Until the middle Middle Cambrian, the carbonate factory in subtidal zones of the Yeongweol platform has not been activated. The Sambangsan Formation is the lowermost second-order sequence (supersequence-1).

During the late Middle Cambrian, tectonic tilting of the North China platform resulted in the drowning of the platform. Formation of a drowning unconformity between the Daegi and Sesong formations in the Taebaek platform has been correlated with that result (Kwon et al., 2006). The drowning probably also occurred in the Yeongweol platform, which caused deepening, resulting in a deep carbonate ramp or slope deposition of the Machari Formation (Fig. 5C). The continued rise of sea level during the Late Cambrian formed a typical ramp sequence, such as the Hwajeol Formaion of the Taebaek Group and the upper Machari and Wagok formations of the Yeongweol Group. They are composed of ribbon limestone, shale, and limestone conglomerate (Fig. 5D). The ramp sequences are characterized by cyclic sedimentation of subtidal shallowing upward successions, showing the superposition of third-order transgressiveregressive sequences (Fig. 3).

In the latest Cambrian and earliest Ordovician, a thick sandstone succession (the Dongjeom Formation) formed in the Taebaek platform. It probably resulted from an abrupt fall of relative sea level and large supply of coarse-grained siliciclastics (Kwon et al., 2006). The fall of relative sea level was most likely caused by diastrophism in the northeastern part of the North China platform (Meyerhoff et al., 1991). The local uplift and the subsequent base-level fall might also have influenced the Yeongweol platform in the latest Cambrian and earliest Ordovician (Fig. 5E). The shallowing by base-level fall probably exposed the Yeongweol platform or submerged the platform at a very shallow level (Fig. 5E). The shallowing can be evidenced by type-I dolomitization which occurred penecontemporaneously, or shortly after deposition of the Wagok Formation, perhaps in an oxidizing environment (Woo and Moore, 1996). During its subsequent burial, the unstable dolomite was entirely recrystallized by deep burial dolomitization. The transgressive-regressive successions from the Machari to Wagok formations constitute the supersequence-2 in the Yeongweol Group.

The resumed sea-level rise during the late Sauk transgression in the Early Ordovician (Tremodocian to Arenigian) formed typical subtidal ramp-type transgressive-regressive successions and successive highstand peritidal cyclic successions (Fig. 3 and $5 F)$. In the Yeongweol platform, the subtidal sequence of the Mungok Formation is correlated with the Dumugol Formation (Tremadocian) in the Taebaek region, whereas the peritidal sequence in the lower part of the Yeongheung Formation can be correlated with the Makgol Formation (Arenigian) in the Taebaek area (Table 3).

A gradual rise of eustatic sea level during the 

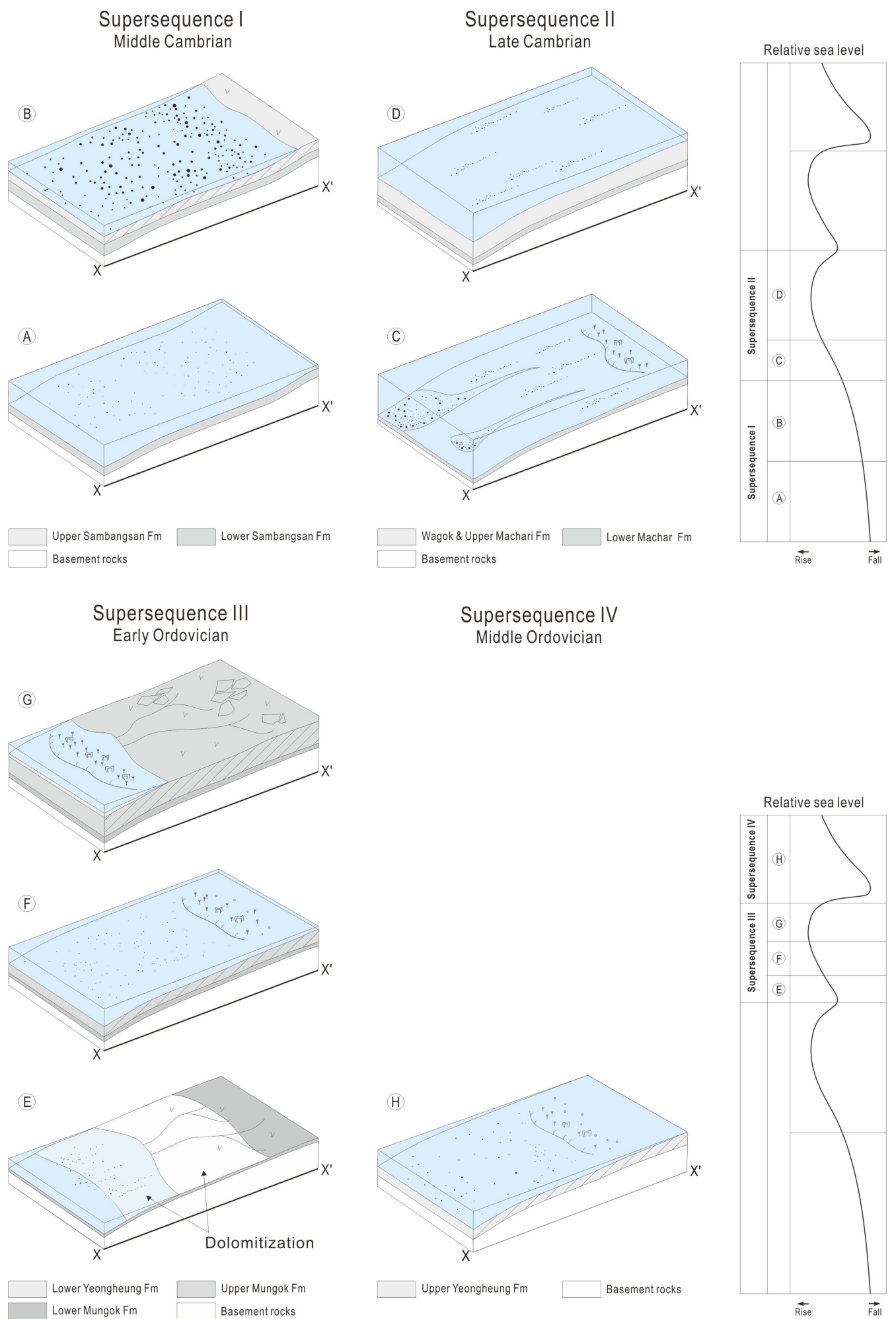

\section{Supersequence IV Middle Ordovician}
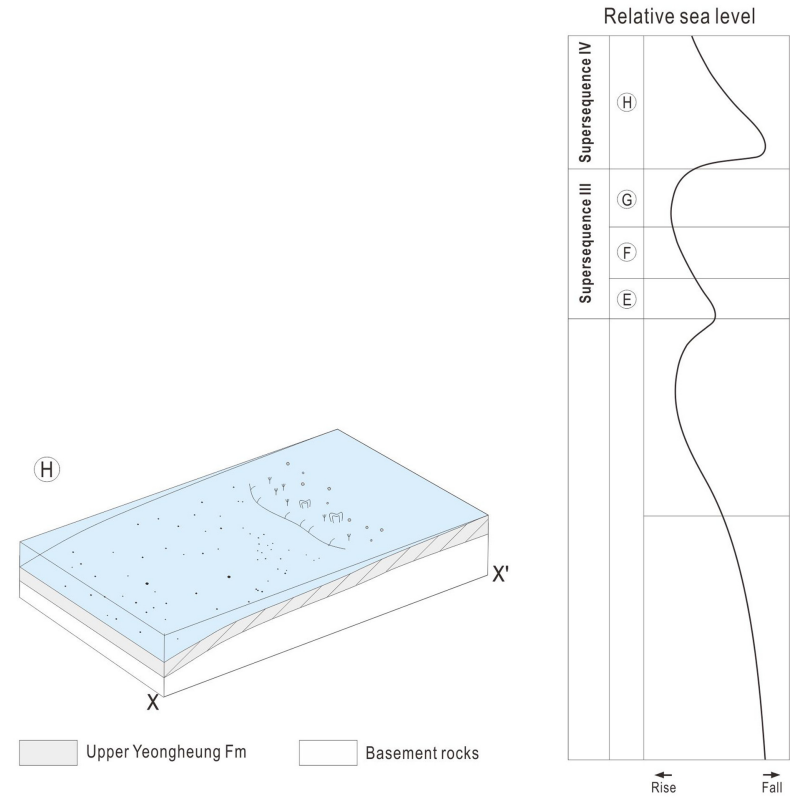

Fig. 5. Sedimentary evolution of the Yeongweol platform sequences. 
Cambrian (Sauk transgression) was maintained until the Early Ordovician (e.g., Vail et al., 1977). During the earliest Middle Ordovician (early Darrwillian), global eustatic fall occurred and generated the globally-recognized bounding surfaces of $1^{\text {st }}$ order megasequences (Sauk and Tippecanoe boundary) (Sloss, 1963). In the Taebaek platform, the megasequence boundary is preserved at the uppermost part of the Makgol Formation (Kwon et al., 2006). In the Yeongweol platform, some evidences of subaerial exposure such as supratidal laminites, evaporite mineral casts, desiccation cracks and tepee structures have been recorded at the lower (or middle) part of the Yeongheung Formation (Figs. 3 and 4K-L; Yoo et al., 1994). These evidences support a broad and significant sea-level fall after deposition of the lower Yeongheung Formation (Fig. 5G). The transgressiveregressive successions from the Mungok Formation to the lower part of the Yeongheung Formation can be interpreted as Supersequence-3, bounded by the Sauk-Tippecanoe sequences. Over the wide exposure surface of the underlying peritidal carbonate successions, a resumed transgression occurred in the Middle Ordovician (Fig. 5H). The Tippecanoe transgression formed the siliciclasticdominated transgressive sequence of the Jigunsan Formation and the overlying carbonate-dominated regressive sequence of the Duwibong Formation in the Taebaek platform (Kwon et al., 2006). In contrast, the Darrwillian and Caradocian Yeongweol sequence is composed of simple stackings of shallowing-upward successions consisting of shallow subtidal and peritidal carbonates (Fig. $5 \mathrm{H}$ ). In the cyclic successions, more than five third-order sequences have been recognized, superimposing second-order sea level fluctuations (Yoo et al., 1994; Yoo and Lee, 1997). The cyclic successions in the middle and upper parts of the Yeongheung Formation comprise the uppermost supersequence-4 in the Yeongweol Group.

In the Yeongweol platform, the successive stacking of carbonate-dominated sequences was maintained, passing through first-order megasequence boundary. The omission of deep platform sequence formed during the early transgression (such as Jigunsan Formation in the Taebaek platform) was probably due to the much more active carbonate factory and too far away sources for supply of siliciclastic sediments.

\section{Discussion}

Among the five formations of the Yeongweol Group, the lower three correspond to the Cambrian sequences, whereas the upper two correspond to the Ordovician sequences. In the Taebaek platform, the Sauk transgression was initiated in the late Early Cambrian, whereas it started in the middle Middle Cambrian in the Yeongweol platform (Fig. 6). The delayed initiation of transgression implies that the basement of the Yeongweol platform might be topographically higher than that of the Taebaek platform. During the Sauk transgression from the Middle Cambrian to Early Ordovician, three supersequences were formed in the Yeongweol platform.

Supersequence-1 (Sambangsan Formation) consists of siliciclastic-dominated units formed during the initial flooding of the platform (Fig. 6). Tectonic tilting and drowning of the North China platform probably occurred in the late Middle Cambrian and might be related to the generation of a type- 3 sequence boundary and the drowning of the Yeongweol platform. On the drowning surfaces, the supersequence-2 (Machari and Wagok formations) was formed in the late Middle and Late Cambrian (Fig. 6). Around the Cambrian and Ordovician boundary, local diastrophism occurred in the northeastern part of the North China platform, resulting in uplifting, base-level fall, and basin rejuvenation. The base-level fall generated the supersequence-3 (Dongjeom, Dumugol and Makgol formations) in the Taebaek Group, whereas in the Yeongweol platform, it also formed the supersequence3 composed of the Mungok Formation and the lower part of the Yeongheung Formation during the Early Ordovician (Fig. 6).

After the relative sea-level drop in the earliest Middle Ordovician between the Sauk and Tippecanou transgression, the supersequence-4 (upper part of the Yeongheung Formation) was formed in the Yeongweol platform (Fig. 6). The supersequence comprises shallowing-upward subtidal and peritidal cyclic successions. In the Yeongweol platform, the continuous stacking of carbonate-dominated successions was maintained, passing through firstorder megasequence boundary. The absence of 


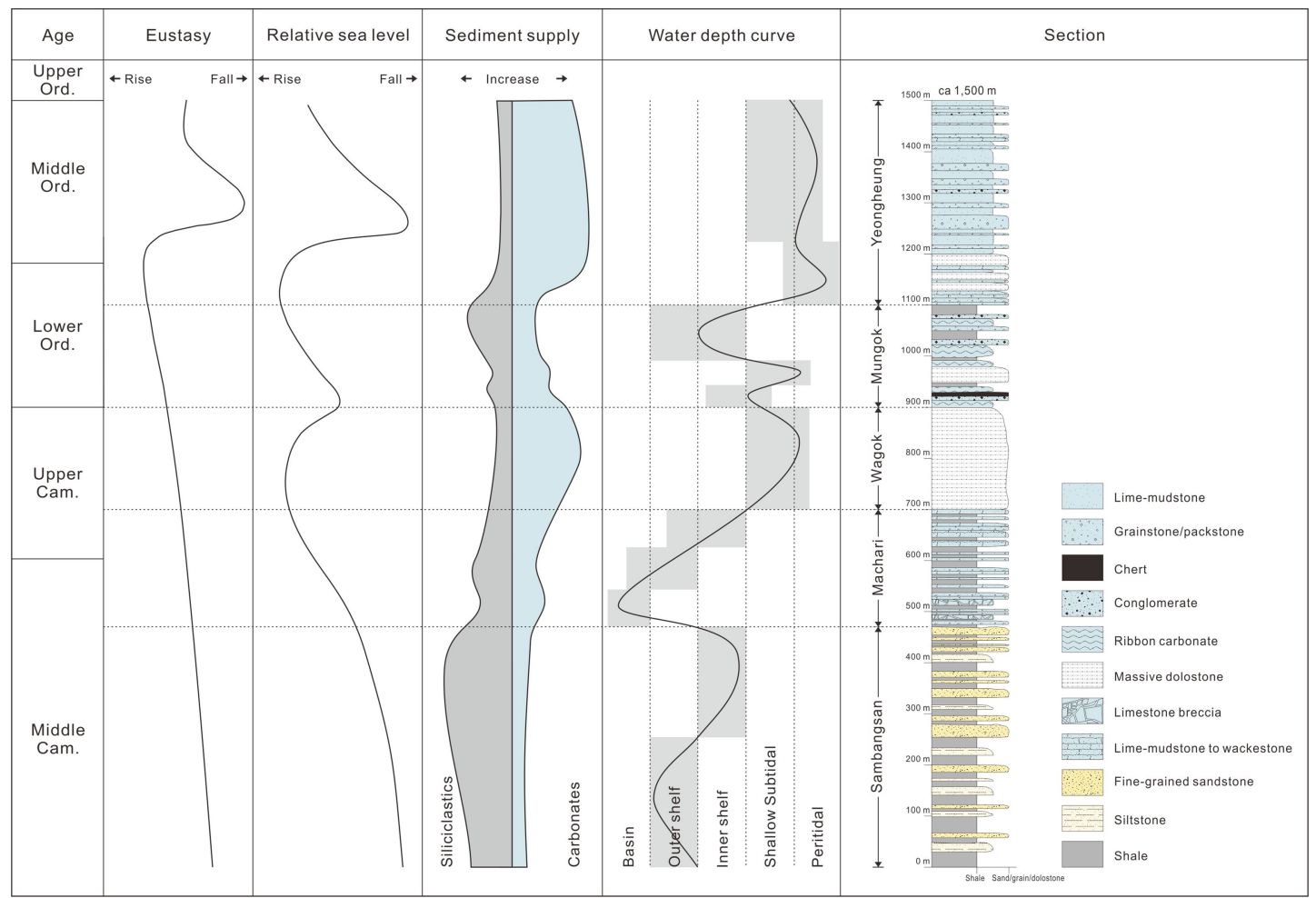

Fig. 6. Sequence stratigraphic interpretation of the Yeongweol Group.

deep platform sequence formed during the early transgression (such as Jigunsan Formation in the Taebaek region) in the Yeongheung Formation can be attributed to a very strong catch up of carbonate factory in the Yeongweol platform which was located far from siliciclastic sources inhibiting the input of such material to the platform.

The paleogeographic relation between the North China platform and Taebaeksan Basin has been a primary concern of geologists working (e.g., Chough et al., 2000; Chough and Choi, 2005; Kwon et al., 2006). According to Kwon et al. (2006) and Woo et al. (2008), the Taebaeksan Basin was located in the northeastern margin of the North China platform. The North China platform sequences have been known to be deposited in a broad and open shallow-marine platform with limited clastic or river-sediment inputs, whereas the Taebaeksan platform sequences were probably formed in a restricted embayment with substantial clastic input (Fig. 7; Kwon et al., 2006).
The Taebaeksan sequences are divided into two large and three relatively smaller lithologic groups. The larger two are the western Yeongweol and eastern Taebaek groups (Fig. 1). On the basis of lithological similarity and paleontological affinity, the Taebaek Group is interpreted as a part of the North China platform (Choi, 1998; Chough et al., 2000; Choi et al., 2004; Kwon et al., 2006). Although the trilobite assemblages suggest that the Yeongweol platform was included in the North China platform (Choi et al., 2001), however, there have been considerable debates on the paleogeographic position of the Yeongweol platform based on the lithologic difference between the Yeongweol platform sequence and other North China platform sequences (Cluzel et al., 1991; Yin and Nie, 1993).

The present work evaluates the sequence stratigraphic interpretation of the Yeongweol platform sequence (Fig. 6) and the paleogeographic correlation between the Yeongweol and Taebaek sequences (Fig. 7). The relative sea-level fluctuations in the Yeongweol platform are very similar to those of 


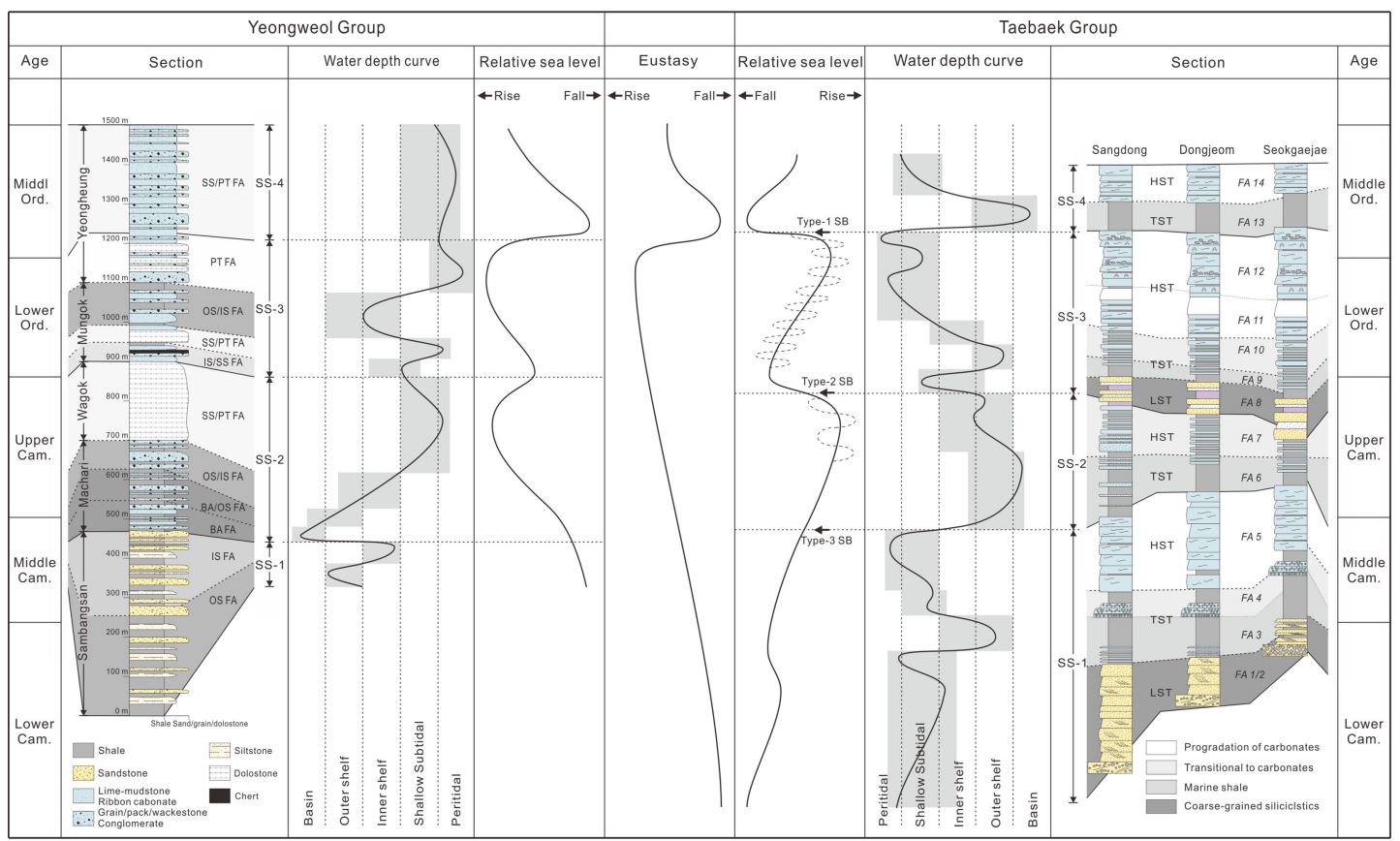

Fig. 7. Sequence stratigraphic correlation between the Yeongweol and Taebaek groups (after Y.K. Kwon et al., 2006).

the Taebaek platform (Fig. 7). The rapid sea-level rise in the late Middle Cambrian resulted in a drowning event in the Yeongweol platform, forming an abrupt deepening represented by the lower Machari Formation (Fig. 6).

The relative sea-level fall in the earliest Ordovician occurred in the Taebaek platform, which might be related to local diastrophism in the northeastern part of the North China platform, subsequent basin rejuvenation and clastic dumping in the shallow platform (Kwon et al., 2006). In the Yeongweol platform, the sea-level drop was documented in the upper part of the Wagok Formation, evidenced by almost syndepositional dolomitization (Fig. 5). The major eustatic sea-level fall between the Sauk and Tippecanoe sequences occurred in the uppermost Makgol Formation of the Taebaek Group (Kwon et al., 2006). In the Yeongweol platform, passing through first-order megasequence boundary, shallowing-upward peritidal cycles were stacked successively with some exposure surfaces (Fig. 3). The exposure has been interpreted as a result of a few third-order relative sea-level falls in the Middle Ordovician (Yoo and Lee, 1997). Among these, the lowermost one can be correlated with first-order eustatic sea level drop between the Sauk and Tippecanoe transgressions (Fig. 8).

According to sequence stratigraphic interpretation, the reconstructed relative sea-level curve of the Yeongweol platform is very similar to that of the Taebaek platform. It suggests that the Yeongweol and Taebaek platform sequences simultaneously experienced the similar tectonic history in the northeastern North China platform during the Cambrian and Ordovician (Fig. 6; Kwon et al., 2006). Based on the absence of coarse-grained clastic sequence and the successive stacking of peritidal platform carbonates in the Early to Middle Ordovician Yeongweol Group, we suggest that the Yeongweol platform was probably located in a relatively open shallow marine environment. Whereas the Taebaek platform was formed in a restricted embayment, possibly located in the northeastern margin of the North China platform (Fig. 9). The Yeongweol platform also had a strong catch up ability of carbonate factory, as it was located far from siliciclastic sources with little input of these components in the platform (Fig. 9). The Yeongweol platform was probably juxtaposed with the Taebaek platform, forming the Joseon 
Yeongweol Group

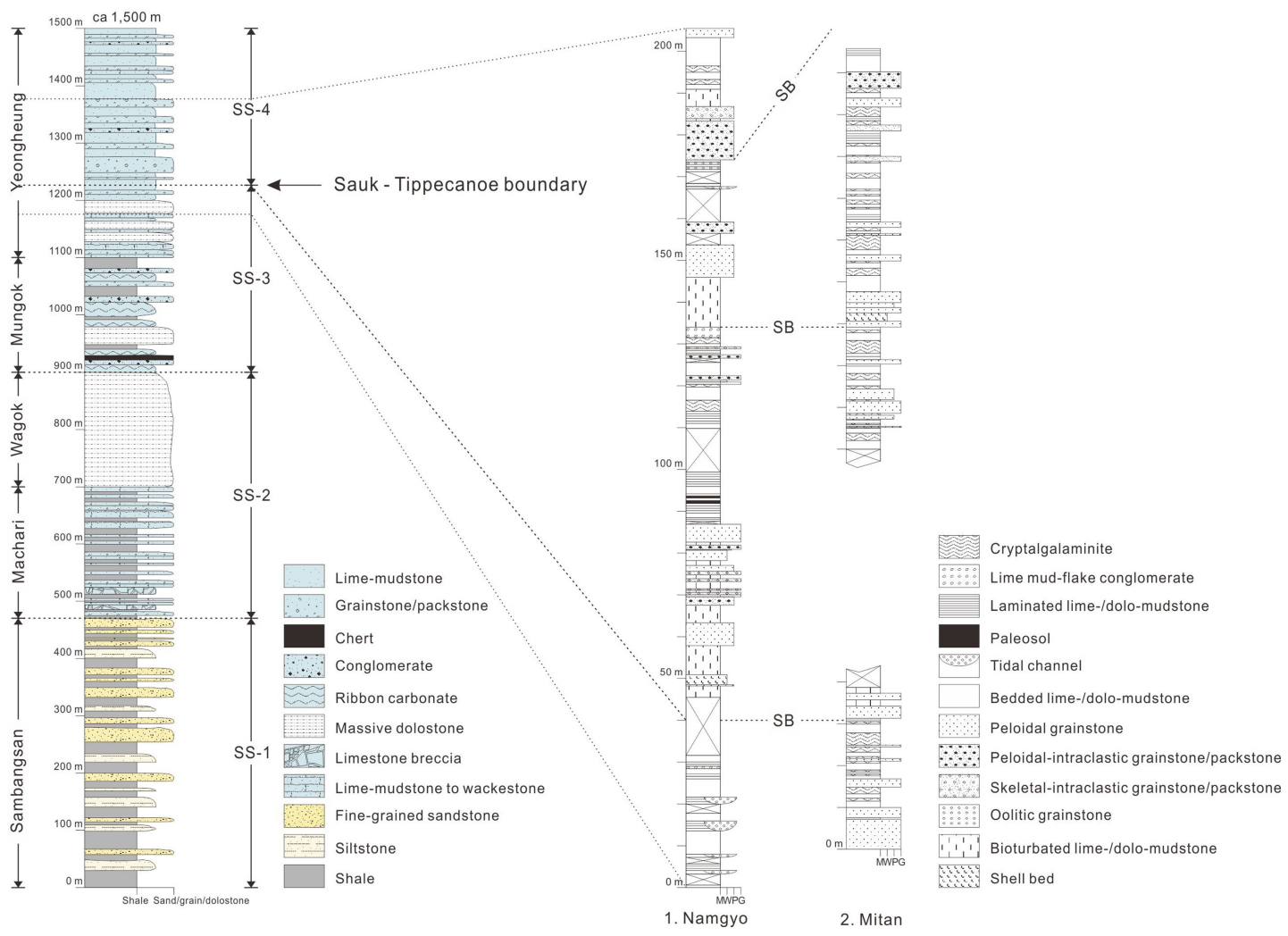

Fig. 8. Stratigraphic position of first order sequence boundary between the Sauk and Tippecanoe sequences within the Yeongheung Formation (modified after C.M. Yoo and Y.I. Lee., 1997).

Supergroup in Taebaeksan Basin through the complex movements associated with the late Paleozoic and early Mesozoic amalgamation between the North and South China blocks (Fig. 9).

\section{Conclusions}

The Yeongweol Group is a Lower Paleozoic mixed carbonate-siliciclastic sequence, and consists of five lithologic formations: Sambangsan, Machari, Wagok, Mungok, and Yeongheung formations in ascending order. The Cambrian-Ordovician Yeongweol Group consists of four second-order sequences (supersequence-1, -2, -3, and -4). Supersequence-1 consists of the Sambangsan Formation (middle Middle Cambrian), lithologically composed of siltstone, shale and sandstone, terminated by rapid deepening of the Yeongweol platform. The overlying supersequence- 2 comprises the Machari and Wagok formations (late Middle to Late Cambrian). The drop and ensuing rise of relative sea level during the latest Cambrian or earliest Ordovician would produce supersequence-3, representing the subtidal platform carbonates (Mungok Formation) and the overlying peritidal platform carbonates (lower part of the Yeongheung Formation). Passing through the Sauk and Tippecanoe boundary, supersequence-4 was formed in the Yeongweol platform during the Middle Ordovician. The reconstructed relative sea-level curve of the Yeongweol platform is very similar to that of the Taebaek platform, suggesting that the Yeongweol platform was located somewhere between the North and South China platforms, much closer to the North China platform. The lithologic and stratigraphic differences imply that the Yeongweol and Taebaek 

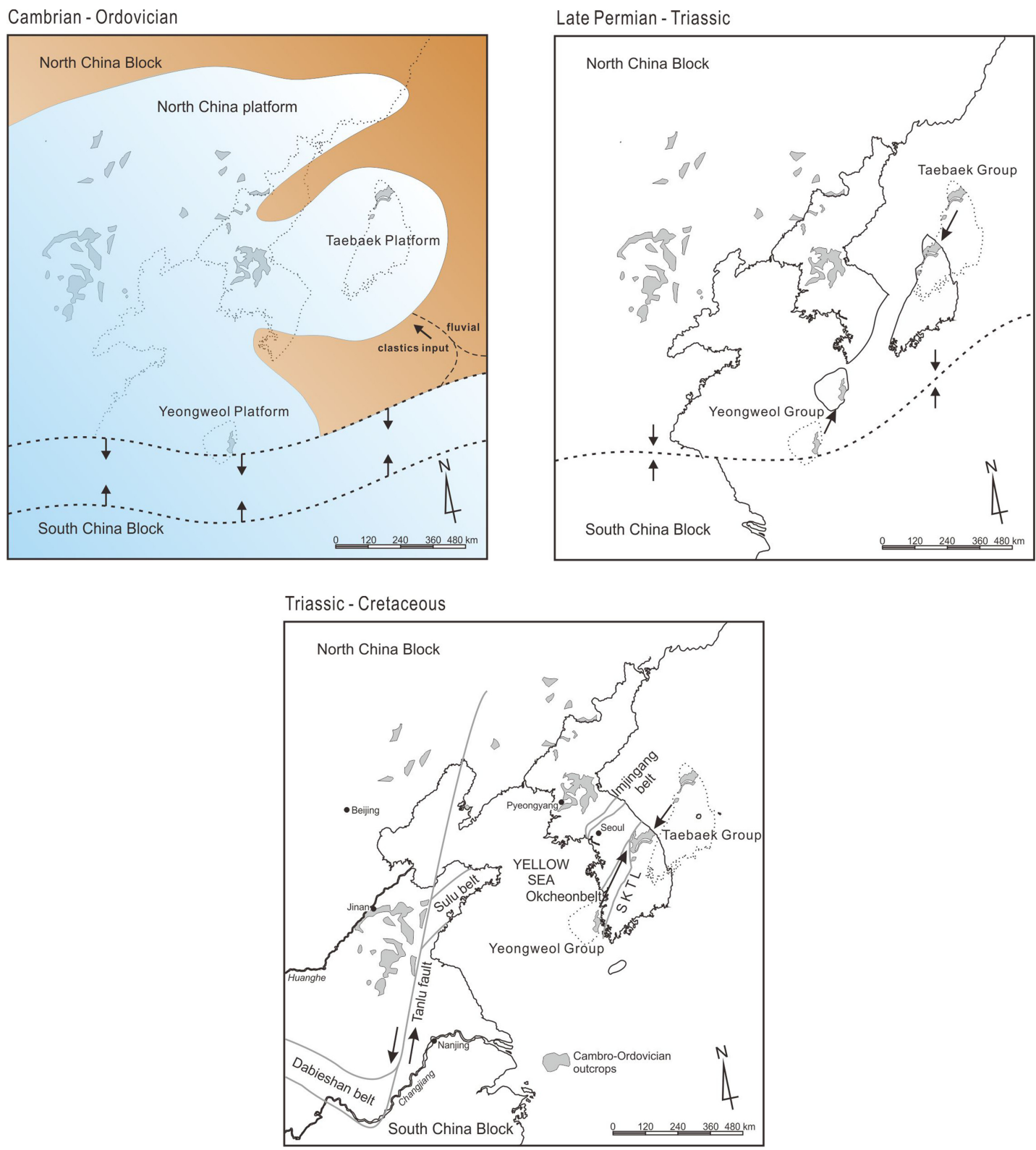

Fig. 9. Paleogeography of the Yeongweol and Taebaek platforms in the North China Platform during the Cambrian and Ordovician.

platforms might not belong to a single depositional system within the North China platform. The Yeongweol platform was probably located in relatively open shallow marine environments, whereas the Taebaek platform was a part of the restricted embayments of the northeastern margin of the North China platform.

\section{Acknowlegements}

This study is funded by Korea Institute of Energy Technology Evaluation and Panning (KETEP2010T100200300). I am grateful to Dr. S.H. Kwon and Dr. D.H. Lee for their helpful reviews and journal editors for useful comments on this manuscript. 


\section{References}

Cheong, C.H. (1969) Stratigraphy and Paleontology of the Sancheog Coalfield, Gangweon-do, Korea: Joural of the Geological Society of Korea, v.5, p.13-54.

Cho, H.S. and Kim, J.Y. (2007) Graptolite biostratigraphy and its correlation of the Mungok and Yeonghung formations at Yeongwol area, Kore: Geosciences Journal, v.11, p.23-38

Choi, D.K. (1998) The Yongwol Group (Cambrian-Ordovician) redefined: a proposal for the stratigraphic nomenclature of the Choson Supergroup: Geosciences Journal, v.2, p.220-234.

Choi, D.K. and Kim, E.Y. (2006) Occurrence of Changshania (Trilobita, Cambrian) in the Taebaeksan Basin, Korea and its stratigraphic and paleogeographic significance: Palaeogeography, Palaeoclimatology, Palaeoecology, v.242, p.343-354.

Choi, D.K., Lee, J.G. and Choi, S.Y. (1999) Middle Cambrian trilobites from the Sambangsan Formation in Yongwol area, Korea: Journal of the Paleontological Society of Korea, v.15, p.134-144.

Choi, D.K., Kim, D.H. and Sohn, J.W. (2001) Ordovician trilobite faunas and depositional history of the Taebaeksan Basin, Korea: Implications for paleogeography: Alcheringa, v.25, p.53-68.

Choi, D.K., Chough, S.K., Kwon, Y.K., Lee, S.B., Woo, J., Kang, I., Lee, H.S., Lee, S.M., Sohn, J.W., Shinn, Y.J. and Lee, D.J. (2004) Taebaek Group (Cambrian-Ordovician) in the Seokgaejae section, Taebaeksan Basin:a refined lower Paleozoic stratigraphy in Korea: Geosciences Journal, v.8, p.125-151.

Choi, D.K. and Chough, S.K. (2005) The Cambrian-Ordovician stratigraphy of the Taebaeksan Basin, Korea: a review: Geosciences Journal, v.9, p.187-214.

Choi, S.J. and Woo, K.S. (1993) Depositional environment of the Ordovician Yeongheung Formation near Machari area, Yeongweol, Kangweondo, Korea: Journal of the Geological Society of Korea, v.29, p.375-386.

Chough, S.K., Kwon, S.-T., Ree, J.-H. and Choi, D.K. (2000) Tectonic and sedimentary evolution of the Korean peninsula: a review and new view: Earth-Science Reviews, v.52, p.175-235.

Chung, G.S. and Land, L.S. (1997) Dolomitization of the periplatform carbonate slope deposit, the Machari Formation (Middle to Late Cambrian), Korea: Carbonates and Evaporites, v.12, p.163-176.

Chwae, U. and Choi, S. (1999) On the Possible Extension of the Sulu Belt Toward the East through the Korean Peninsula: Gondwana Research, v.2, p.540-542.

Cluzel, D., Jolivet, L. and Cadet, T.-P. (1991) Early middle Paleozoic intraplate orogeny in the Ogcheon belt (South Korea): a new insight on the Paleozoic buildup of East Asia: Tectonics, v.10, p.1130-1151.

Hong, P., Lee, J.G. and Choi, D.K. (2003) Lejopyge armata and associated trilobites from the Machari Formation (Middle to Late Cambrian) of Korea and their stratigraphic significance: Journal of Paleontology, v.77, p.895-907.

Kim, S.W. (2005) Amphibole 40Ar/39Ar Geochronology from the Okcheon Metamorphic Belt, South Korea and its Tectonic Implications: Gondwana Research, v.8, p.385-402.

Kim J.C. and Lee, Y.I. (1996) Marine diagenesis of Ordovician Carbonate sediments, Korea: Sedimentary Geology, v.105, p.241-257.

Kim, J.H., Lee, Y.I., Li, M. and Bai, Z. (2001) Comparison of the Ordovician-Carboniferous Boundary Between Korea and NE China: Implications for Correlation and Tectonic Evolution: Gondwana Research, v.4, p.39-53.

Kim, D.H. and Choi, D.K. (2000) Lithostratigraphy and biostratigraphy of the Mungok Formation (Lower Ordovician), Yongwol, Korea: Geoscience Journal, v.4, p.301-311.

Kim, D.H. and Choi, D.K. (2002) Facies of a Lower Ordovician carbonate shelf (Mungok Formation: Taebaeksan Basin, Korea): Facies, v.47, p.43-56.

Kobayashi, T. (1966) The Cambro-Ordovician formations and faunas of South Korea: Part 10, stratigraphy of the Chosen Group of Korea and South Manchuria and its relation to the Cambro-Ordovician formations of other areas. section A, The Chosen Group of South Korea: Journal of the Faculty of Science. Imperial University of Tokyo, v.2, p.1-84.

Kwon, Y.K., Lee, D.J., Choi, D.K. and Chough, S.K. (2003) Lower Ordovician sponge bioherms in the Makkol Formation, Taebaeksan Basin, Mideast Korea: Facies, v.48, p.79-90.

Kwon, Y.K., Chough, S.K., Choi, D.K. and Lee, D.J. (2006) Sequence stratigraphy of the Taebaek Group (Cambrian-Ordovician), Mideast Korea: Sedimentary Geology, v.192, p.19-55.

Kwon, S., Sajeev, K., Mitra, G., Park, Y., Kim, S.W. and Ryu, I.C. (2009) Evidence of Permo-Triassic collision in Far East Asia: the Korean collisional orogen: Earth and Planetary Science Letters, v.279, p.340-349.

Lee, H.Y. (1987) Paleozoic Erathem, Choson Supergroup: In: Lee, D.S. (Ed.), Journal of the Geological Society of Korea, Seoul, p.49-82.

Lee, J.G. (1995) Late Cambrian Trilobites from the Machari Formation, Yeongweol, Korea: Ph.D. thesis, Seoul National University, Seoul, 418p.

Lee, Y.I. and Kim, Y. (2001) Characterization of Quartzites in the Southern Korean Peninsula: Gondwana Research, v.4, p.677-678.

Meng, X., Ge, M. and Tucker, M.E. (1997) Sequence stratigraphy, sealevel changes and depositional systems in the Cambro-Ordovician of the North China carbonate platform: Sedimentary Geology, v.114, p.189-222.

Metcalfe, I. (2006) Palaeozoic and Mesozoic tectonic evolution and palaeogeography of East Asian crustal fragments: The Korean Peninsula in context: Gondwana Research, v.9, p.24-46.

Meyerhoff, A.A., Kamen-Kaye, M., Chen, C. and Taner, I. (1991) China-Stratigraphy, Paleogeography, and Tectonics: Kluwer Academic Publishers, Dordrecht, The Netherlands.

Oh, C.H. (2006) A new concept on tectonic correlation between Korea, China and Japan: Histories from the late Proterozoic to Cretaceous: Gondwana Research, v.9, p.47-61.

Oh, C.H., Krishan, S., Kim, S.W. and Kwon, Y.W. (2006) Mangerite magmatism associated with a probable Late- 
Permian to Triassic Hongseong-Odesan collision belt in South Korea: Gondwana Research, v.9, p.95-105.

Park, K.K., Choi, D.K. and Kim, J.H. (1994) Mungog Formation (Lower Ordovician) in the northern part of Yeongweol area: lithostratigraphic subdivision and trilobite faunal assemblages: Journal of the Geological Society of Korea, v.30, p.168-181.

Ree, J.H., Cho, M., Kwon, S.T. and Nakamura, E. (1996) Possible eastward extension of Chinese collision belt in South Korea : The Imjingang Belt: Geology, v.24, p.1071-1074.

Ryu, I., Oh, C.H. and Kim, S.W. (2005) A Middle Ordovician Drowning Unconformity on the Northeastern Flank of the Okcheon (Ogcheon) Belt, South Korea: Gondwana Research, v.8, p.511-528.

Sepkoski, J.J.Jr. (1982) Flat-pebble conglomerates, storm deposits, and the Cambrian bottom fauna: In: Einsele, G., Seilacher, A. (Eds.), Cyclic Event and Stratification, p.371-388.

Sloss, L.L. (1963) Sequences in the cratonic interior of North America: Geological Society of America Bulletin, v.74, p.93-114.

Vail, P.R., Mitchum Jr., R.M. and Thompson, S. (1977) Seismicstratigraphy and global changes of sea level: In: Payton, C.E. (Ed.), Seismic Stratigraphy-Applications to Hydrocarbon Exploration: AAPG Memoir, American Association of Petroleum Geologists (AAPG), v.26, p.83-97.

Woo, J., Chough, S.K. and Han, Z. (2008) Chambers of Epiphyton thalli in microbial buildups, Zhangxia Formation (Middle Cambrian), Shandong Province, China: Palaios, v.23, p.55-64

Woo, K.S. and Moore, C.H. (1996) Burial dolomitization and dedolomitization of the Late Cambrian Wagok Formation, Yeongweol, Korea: Carbonates and Evaporites, v.11, p.104-112.

Woo, K.S. and Park, B.K. (1989) Depositional environments and diagenesis of the Sedimentary rocks, Choseon Supergroup, Korea: past, present, and further; the state of the art: Journal of the Geological Society of Korea, v.25, p.347-363.

Yin, A. and Nie, S. (1993) An indentation model for the North and South China collision and development of the Tan-Lu and Honam fault systems, eastern Asia: Tectonics, v.12, p.810-813.

Yosimura, I. (1940) Geology of the Neietsu District, Kogendo, Tyosen: Journal of the Geological Society of Japan, v.40, p.112-122.

Yoo, C.M., Lee, Y.I. and Paik, I.S. (1994) Evidence for hypersaline conditions in the Middle Ordovician Yeongheung formation, Korea: Journal of the Geological Society of Korea, v.30, p.355-368.

Yoo, C.M. and Lee, Y.I. (1997) Depositional cyclicity of the Middle Ordovician Yeongheung Formation, Korea: Carbonates \& Evaporites, v.12, p.192-203.

Zhai, M., Shao, J., Hao, J. and Peng, P. (2003) Geological Signature and Possible Position of the North China Block in the Supercontinent Rodinia: Gondwana Research, v.6, p.171-183.

Zhai, M., Guo, J., Li, Z., Chen, D., Peng, P., Li, T., Hou, Q. and Fan, Q. (2007) Linking the Sulu UHP belt to the Korean Peninsula: Evidence from eclogite, Precambrian basement, and Paleozoic sedimentary basins: Gondwana Research, v.12, p.388-403.

Zhang, Z., Robson, S.P., Emig, C. and Shu, D. (2008) Early Cambrian radiation of brachiopods: A perspective from South China: Gondwana Research, v.14, p.241-254.

2012년 5월 24일 원고접수, 2012년 6월 11일 게재승인 